\section{Maternal feeding practice and its relationship with stunting in children}

\author{
Prihatini Dini Novitasari, Dessie Wanda \\ Faculty of Nursing, Universitas \\ Indonesia
}

\begin{abstract}
The incidence of stunting in children is a crucial problem that remains challenging to tackle and is caused by multiple factors. This study aimed to determine the relationship between maternal feeding practice and the incidence of stunting in children in Depok, Indonesia. The study design was a correlation analysis with a cross-sectional approach including applied height-for-age z-score tables from the World Health Organization (WHO) and a feeding practices and structure questionnaire (FPSQ28). The study involved 262 participants who were selected using a cluster random sampling technique in 11 district health centers in Depok. The results suggest that there was no significant relationship between maternal feeding practice and the incidence of stunting in children in Depok $(\mathrm{P}>0.05)$. In addition, feeding practice performed by mothers was rather non-responsive. The study results are expected to provide benefits for nurses and health professionals in order to improve health education and promotion programs related to stunting and responsive feeding practice.
\end{abstract}

\section{Introduction}

Stunting is a clinical manifestation of chronic malnutrition and a crucial issue that remains challenging to overcome. The World Health Organization defined stunting as a condition in which the height-for-age ratio (H/A) is less than a -2 standard deviation (SD). Stunting is characterized by failure in three aspects: growth, development, and metabolism. ${ }^{1}$ It is imperative to tackle this issue since it may result in negative impacts on quality of life, including growth and development, health, and economic outcomes. ${ }^{2,3}$ However, at present, the issue remains unsolved. In 2017, it was estimated that $22.2 \%$ or 150.8 million toddlers across the globe are affected by stunting. ${ }^{4}$ In Indonesia, according to RISKESDAS 2018, $30.8 \%$ of toddlers are affected, with the proportion of stunted toddlers at approximately $19.3 \%$ and the proportion of severely stunted toddlers at approximately $11.5 \% .^{5}$ Specifically, in West Java, according to
RISKESDAS 2013 in the West Java Provincial Health Office, $35.3 \%$ of toddlers are affected by stunting. In Depok, the percentage of toddlers with stunting amounts to $25.7 \%$.

This high prevalence may be associated with various risk factors affecting stunting, including maternal and child medical history, $2,3,7$ maternal and child nutritional status, 8,9 the gender of the child, 2,8 environment, ${ }^{2,3,7}$ economic condition of household, ${ }^{8}$ the mother's educational background, 7,8 and the number of toddlers in a family. ${ }^{2}$ Inadequate nutrition, which may contribute to stunting, is associated with ineffective feeding practice, in which an increase in nutritional demand is not fulfilled with proper quality and quantity of feeding practice. ${ }^{3}$

Based on the pilot study and study literature, feeding practice may affect the quality and quantity of nutrition provided to children. The effectiveness of it is essential as it improves children's nutritional status, which leads to a lower prevalence of stunting. ${ }^{3}$ Mugode, Puoane, Michelo, and Steyn reported that responsive feeding is an effective practice for meeting a child's nutritional requirements to prevent stunting. 10 In addition, Black and Hurley also affirmed that it is an alternative solution with which to manage feeding difficulties and picky eating in children. ${ }^{11}$ Moreover, according to a study conducted by Abebe, Desse, and Baye, mothers' non-responsive feeding behaviors are higher among children with stunting than those without stunting. ${ }^{2}$ Nevertheless, there had never been a study conducted to address the relationship between maternal feeding practice and stunting in children aged 2 to 5 years in Depok. Consequently, the authors aimed to conduct a study addressing the relationship between maternal feeding practice and stunting in children in Depok. It was expected to answer inquiries concerning the absence of a correlation between the two circumstances in this region.

\section{Materials and Methods}

This study employed a cross-sectional approach. The independent variable of the study was maternal feeding practice, while the dependent variable was stunting. The researcher also identified respondents' characteristics, including mother's age and educational background, the number of toddlers in a household, household income per month, the child's gender, and the frequency of infectious disease (diarrhea, Upper Respiratory Tract Infection/URTI) affecting the child.
Correspondence: Dessie Wanda, Pediatric Nursing Department, Faculty of Nursing, Universitas Indonesia, Jalan Prof. Dr. Bahder Djohan, Kampus UI Depok, West Java, 16424 Indonesia.

Tel.: +6221.78849120 - Fax: +6221.7864124.

E-mail: dessie@ui.ac.id

Key words: Children under 5 years of age; maternal feeding practice; stunting.

Acknowledgments: The authors would like to express their gratitude to the Directorate of Research and Community Services of Universitas Indonesia and the enumerators who were involved in this study, all respondents, and the presentation of the $4^{\text {th }}$ International Conference of Global Health.

Funding: This study was supported by Hibah PITTA B 2019, funded by DRPM Universitas Indonesia (No. NKB-0488/UN2.R3.1/HKP.05. 00/2019).

Contributions: PDN and DW conceived the idea and plan of research. PDN and DW contributed to the design and implementation of the research also verified the analytical method. PDN wrote the manuscript in consultation with DW. All authors discussed the results and reviewed the final manuscript.

Ethical approval: This study obtained an ethical approval letter from the Research Ethics Committee of the Faculty of Nursing Universitas Indonesia (No.99/UN2.F12.D/HKP.02.04/2019).

Conflict of interest: The authors have no conflict of interest.

This work is licensed under a Creative Commons Attribution NonCommercial 4.0 License (CC BY-NC 4.0).

(C) Copyright: the Author(s), 2020

Licensee PAGEPress, Italy

Pediatric Reports 2020; 12(s1):8698

doi:10.4081/pr.2020.8698

In total, 262 participants were selected using a cluster random sampling technique in which 11 district health centers. The inclusion criteria were: i) toddlers aged 2 to 5 years and their mothers residing in Depok, West Java, Indonesia; and ii) literate mothers. The exclusion criteria included participants who did not provide all the data due to their children being finicky or who were required to undergo further tests.

Data collection process included anthropometric measurements, a review of the medical records of children affected by diarrhea and/or an upper respiratory tract infection (URTI) in the previous six months, and completion of questionnaires by the mothers. 
The study instruments included height-forage z-score tables from the WHO, demographic characteristics, and feeding practices and structure questionnaire (FPSQ-28). The FPSQ-28 was developed by Jansen, Williams, Mallan, Nicholson, and Lynne to evaluate maternal feeding practice. ${ }^{13}$ The questionnaire was translated using a backtranslation technique into the Indonesian language. Permission to use the questionnaire was granted by its developers. Furthermore, the authors conducted validity and reliability tests on 30 participants in the Beji District Health Center. Two out of 28 questions had a p-value lower than alpha 5\%, which was later modified. The Cronbach's alpha value was 0.75 .

Univariate analysis was applied for the variable of maternal feeding practice, and the frequency distribution analysis was applied for other variables. Bivariate analysis was applied for maternal feeding practice and stunting incidence by using the Spearman's rank correlation coefficient test and the Eta test. Gamma correlation tests were performed to identify the relationship between the characteristics of the respondents and the incidence of stunting. Fisher's exact test was applied to identify any correlation between a child's gender and stunting.

\section{Results}

The majority of mothers involved in this study were early adults (19-35 years old) $(65.6 \%)$, were high school graduates $(76.7 \%)$, and had one toddler $(62.6 \%)$. Based on household income per month, most participants had equal/below the Regional Minimum Wage (72.9\%). It also describes that the majority of children were males. Moreover, $63.7 \%$ of children were frequently affected by infectious disease (diarrhea, URTI), which means they experienced it more than once in the previous 6 months. The proportion of children with stunting was $13.7 \%$, as described in Table 1 .

The description of maternal feeding practice is provided in Table 2. Maternal feeding practice was measured based on seven subscales, including reward for behavior, reward for eating, persuasive feeding, overt restriction, covert restriction, structured meal setting, and structured meal timing. All subscales were not normally distributed, as indicated by $\mathrm{P}<0.05$ according to the Kolmogorov-Smirnov normality test; thus, the median value was applied.

The relationship between maternal feeding practice and stunting incidence in children is outlined in Table 3 .

Table 3 shows that there was no significant association between maternal feeding practice and stunting in children. The positive correlation coefficient implies that the association of maternal feeding practice was directly proportional to stunting incidence in children in Depok. It also means that the higher score of maternal feeding practice (less responsive), the higher stunting incidence among children.

The description of the relationship between maternal and children's characteristics and stunting incidence in children is delineated in Table 4.

Based on the analysis, the frequency of children being affected by the infectious disease was significantly associated with stunting incidence, with a P-value of 0.012 $(\mathrm{P}<0.05)$ and a correlation coefficient of 0.451 , which implies a moderate strength of correlation. Though a significant relationship was absent, Table 4 also suggests that children with stunting were mostly identified with early adult mothers; middle school graduate mothers; a mother with more than one toddler; and had families from lowermiddle-class backgrounds than from upperclass backgrounds. Nevertheless, stunting may affect both male and female children, as indicated by the equal percentages found.

\section{Discussion}

\section{Stunting incidence in children}

The proportion of stunting in children in Depok is $13.7 \%$ of 262 child study respon-

Table 1. The proportion of stunting incidence in children.

\begin{tabular}{lcc} 
Height for age status & Frequency (n) & Percentage (\%) \\
Normal & 226 & 86.3 \\
\hline Stunting & 36 & 13.7 \\
\hline
\end{tabular}

Table 2. Description of maternal feeding practice.

\begin{tabular}{lccr} 
Variable & Median & Min-Max & $95 \%$ CI \\
Maternal feeding practice & 98 & $51-124$ & $95.75-98.67$ \\
\hline
\end{tabular}

dents. This proportion is categorized as low because it is less than $20 \%, 14$ and it is still lower than the $25.7 \%$ stunting prevalence in toddlers in Depok in 2013.6 ${ }^{\text {This result }}$ shows that the proportion found at present is only half of the prevalence in 2013, so it can be assumed that programs designed to reduce stunting prevalence are succeeding in this region. It may be because the percommunity health center has improved. However, the stunting proportion found in this study must be considered and must continue to be reduced to the lowest level that can be achieved.

\section{The relationship between maternal feeding practice and stunting incidence in children}

In this study, most of the mothers carried out less responsive feeding practices. This phenomenon shows that mothers paid less attention to the signs of child hunger, provided food that is not in accordance with the expected appetite for children, and either encouraged their children to eat a great deal or limited their eating. 15 The lack of mothers' ability in choosing the right food for their children was also found in a previous study in the same location. ${ }^{16}$ The high level of non-responsive feeding behavior is also in line in Zambia, in which only a small proportion of mothers fed slowly or tried to provide alternative food for children. 10

From the study, persuasive feeding carried out by most mothers in Depok was quite high. The majority of mothers persuaded children in various ways without noticing the signs of hunger and fullness. Furthermore, overt and covert restriction of formance of nutritional installation in each

Table 3. Description of correlation between maternal feeding practice and stunting incidence in children in Depok, April 2019 ( $\mathrm{n}=262$ ).

\begin{tabular}{lccccccc} 
& \multicolumn{2}{c}{ Median (Min-Max) } & \multicolumn{2}{c}{ Mean (SD) } & P & P \\
& Normal & Stunting & Normal & Stunting & \\
Maternal feeding practice-stunting & $98(51-121)$ & $97(74-124)$ & $97.13(12.30)$ & $97.67(9.971)$ & 0.853 & 0.381 \\
\hline
\end{tabular}


children's desire to eat were also found still dominantly carried out by mothers in Depok. Restricted food intake affects the amount of nutrition that children can receive and is related to the nutritional status of children. ${ }^{3}$ This restriction is carried out by the mothers because of their perceptions and concerns that the child may be taking in excessive amounts of food. ${ }^{17}$ According to Freitas et al., this non-responsive feeding action increases when the mother feels her child has excess weight. ${ }^{17}$ This restriction has been one of the related factors of stunting according to Dranesia, Wanda, and Hayati. ${ }^{18}$ Moreover, the structured meal setting and structured meal timing subscales are still dominated by mothers. This demonstrates that the type of feeding practice carried out by mothers is authoritarian, in which maternal control is greater than the children's control. ${ }^{11,19}$ As a result, children have no choice but to follow the eating patterns forced on them by their mothers. ${ }^{19,20}$

\section{Relationship between maternal and children's characteristics and stunting in children}

\section{Maternal characteristics}

In this study, most participants were early adults, 19-35 years old, and the majority of stunted children were associated with mothers from this age category. It occurs maybe because, in this category, the mothers are within the productive working age range, which leads to reduced attention to a child's nutrition. It is also shown by the proportion of stunting based on the mother's age, in which participants aged below 35 years were more likely to have a stunted child. Ntenda and Chuang stated that stunted children are more commonly found among younger mothers than older ones. ${ }^{8}$ According to literatures, giving birth to a child in adolescence is a risk factor for stunting, 3,8 maybe because adolescent mothers lack experience and knowledge regarding the nutritional needs of children.

In addition, the majority of mothers with stunted children only had one toddler. There are two possible explanations for this: either they only had one child, or they had another child, but that child was older. However, the result suggests no significant association between the number of toddlers and stunting incidence. The result disagrees with previous studies, which revealed that the number of toddlers in a family is a risk factor for stunting. 2,8 It is associated with family's ability to meet the nutritional requirements of its members, especially the toddlers. Families may have had more than one child but not a toddler, and it also affects the nutrients provided for each child or family member.
Finally, the majority of participants had low incomes, which classified them as lowmiddle-class, and stunted children were commonly seen in families with such economic conditions. This can be seen by most visitors of health centers using national health coverage. People who had low income presumably have difficulty in buying foods for their family. Moreover, the majority of participants were early adults and had low-middle educational backgrounds, which was associated with lower economic status due to the difficulty of finding a job. ${ }^{21}$ The number of toddlers is also linked with economic status, in that a lower-class family with more than one toddler is more likely to have an undernourished toddler. ${ }^{2}$

\section{Children's characteristics}

The majority of the children involved in this study were males, though stunting may affect both males and females. This study revealed no significant link between a child's gender and stunting incidence. This result is not in line with Ntenda and Chuang study reporting that stunting mostly affects male children. According to Ntenda and Chuang, this may be because a male child is more likely to be affected by environmental stress than a female child. ${ }^{8}$ Still, the proportion of male children with stunting in this

Table 4. Description of association between maternal and children's characteristics and stunting incidence in children.

\begin{tabular}{|c|c|c|c|c|c|c|}
\hline Participants' characteristics & \multicolumn{2}{|c|}{ Normal } & \multicolumn{2}{|c|}{ Stunting } & $P$ & $\mathbf{r}$ \\
\hline \multicolumn{7}{|l|}{ Mother's age } \\
\hline Middle adult & 75 & 33.2 & 12 & 33.3 & & \\
\hline Early adult & 149 & 65.9 & 23 & 63.9 & 0.899 & -0.024 \\
\hline Late adolescent & 2 & 0.9 & 1 & 2.8 & & \\
\hline \multicolumn{7}{|c|}{ Mother's educational background } \\
\hline High School & 30 & 13.3 & 4 & 11.1 & & \\
\hline Middle School & 174 & 77 & 27 & 75 & 0.482 & 0.141 \\
\hline Elementary School/Unschooled & 22 & 9.7 & 5 & 13.9 & & \\
\hline \multicolumn{7}{|l|}{ Number of toddlers } \\
\hline 1 toddler & 143 & 63.3 & 21 & 58.3 & 0.576 & 0.103 \\
\hline More than 1 toddler & 83 & 36.7 & 15 & 41.7 & & \\
\hline \multicolumn{7}{|l|}{ Household income per month } \\
\hline Above RMW & 63 & 27.9 & 8 & 22.2 & 0.456 & 0.150 \\
\hline Equal to/below RMW & 163 & 72.1 & 28 & 77.8 & & \\
\hline \multicolumn{7}{|l|}{ Children's gender } \\
\hline Female & 99 & 43.8 & 18 & 50 & 0.589 & 0.482 \\
\hline Male & 127 & 56.2 & 18 & 50 & & \\
\hline \multicolumn{7}{|c|}{ Frequency of children affected by infectious disease } \\
\hline Rarely & 88 & 38.9 & 7 & 19.4 & 0.012 & \\
\hline Frequently & 138 & 61.1 & 29 & 80.6 & 0.451 & \\
\hline
\end{tabular}

RMW, regional minimum wage. 
study is higher than with female children.

Furthermore, children are mostly affected by infectious diseases such as diarrhea and URTI. Previous data collected during the rainy season may contribute to this result, and several mothers reported that their children were infected from within their own family or by a neighbor. Isnaini also reported that most children suffered from infectious disease in the six months preceding that study. 22 The result indicates a significant association between the frequency of infectious disease affecting a child and stunting. This suggests that children who are frequently affected by the infectious disease are more likely to be stunted than those who rarely or never suffer from it. Diarrhea is the most common infectious disease seen in toddlers, and it leads to the loss of micronutrients necessary for the body and affects the linear growth of the child. ${ }^{3}$ The frequency of diarrhea in the previous two weeks is a risk factor for stunting among children in Malawi and the history of infectious disease (diarrhea and URTI) is a risk factor for stunting. 8,21 The risk occurs due to the disease impairs nutritional absorption and increases metabolic requirements. ${ }^{23}$

\section{Conclusions}

The total number of participants involved in this study consisted of 262 mothers with toddlers aged 2 to 5 years who live in Depok, and the study was conducted in 11 district health centers in the Depok area. Maternal feeding practice in Depok was mostly less responsive or non-responsive feeding. The prevalence of children with stunting in Depok in April 2019 was lower than the previous data in 2013. There was no significant correlation between maternal feeding practice and stunting in children in Depok. The frequency of children affected by infectious disease in the six months preceding the study was significantly associated with stunting incidence in Depok $(\mathrm{P}=0.012 ; \mathrm{P}<0.05)$.

\section{References}

1. Pritasari K. Upaya percepatan penurunan stunting: Evaluasi pelaksanaan tahun 2018 \& rencana tindak tahun 2019. The Ministry of Health Republic of Indonesia; 2018:1-47. Available from: https://www.kemkes.go.id/ resources/download/info-terkini/ materi_rakorpop_2018/Evaluasi\%202
018\%20dan\%20Rencana $\% 20$ Tindak\% 20Lanjut $\% 20$ Penurunan $\% 20$ Stunting. pdf

2. Nkurunziza S, Meessen B, Van geertruyden JP, Korachais C. Determinants of stunting and severe stunting among Burundian children aged 6-23 months: Evidence from a national cross-sectional household survey. BMC Pediatr 2017;17:1-15.

3. Prendergast AJ, Humphrey JH. The stunting syndrome in developing countries. Paediatr Int Child Health 2014;34:250-65.

4. UNICEF, WHO, World Bank Group. Levels and trends in child malnutrition: Key findings of the 2018 edition of the joint child malnutrition estimates; 2018. Available from: https://www.who.int/ nutgrowthdb/2018-jme-brochure.pdf

5. Agency of Health Research and Development Indonesia. Hasil utama riskesdas 2018. The Ministry of Health Republic of Indonesia; 2018. Available from: https://www.persi.or.id/images/ 2017/litbang/riskesdas launching.pdf

6. West Java Provincial Health Office. Profil kesehatan Provinsi Jawa Barat 2016. The Ministry of Health Republic of Indonesia; 2017. Available from: https://www.kemkes.go.id/resources/do wnload/profil/PROFIL_KES_PROVIN SI_2016/12_Jabar_2016.pdf

7. Beatty A, Ingwersen N, Leith W, Null C. Stunting prevalence and correlates among children in Indonesia. Mathematica Policy Research 2017;1-6.

8. Ntenda PAM, Chuang YC. Analysis of individual-level and community-level effects on childhood undernutrition in Malawi. Pediatr Neonatol 2018;59: 380-9.

9. Perkins JM, Kim R, Krishna A, et al. Understanding the association between stunting and child development in lowand middle-income countries: Next steps for research and intervention. Soc Sci Med 2017;193:101-9.

10. Mugode RH, Puoane T, Michelo C, Steyn NP. "Feeding a child slowly": A responsive feeding behavior component likely to reduce stunting: populationbased observations from rural Zambia. Journal of Hunger \& Environmental Nutrition 2018;13:455-69.

11. Black MM, Hurley M. Responsive feeding: Strategies to promote healthy mealtime interactions. Nestle Nutr Inst Workshop Ser 2017;87:153-65.

12. Abebe Z, Haki GD, Baye K. Child feeding style is associated with food intake and linear growth in rural Ethiopia. Appetite 2017;116:132-8.

13. Jansen E, Williams KE, Mallan KM, et al. The feeding practices and structure questionnaire (FPSQ-28): A parsimonious version validated for longitudinal use from 2 to 5 years. Appetite 2016;100:172-80

14. Wiyogowati C. Kejadian stunting pada anak berumur di bawah lima tahun (059 bulan) di Provinsi Papua Barat Tahun 2010 (Analisis Data Riskesdas 2010). [unpublished thesis]. Depok: Universitas Indonesia; 2012.

15. Finnane JM, Jansen E, Mallan KM, Daniels LA. Mealtime structure and responsive feeding practices are associated with less food fussiness and more food enjoyment in children. J Nutr Educ Behav 2017;49:11-8.

16. Setyaningsih, SR, Agustini, N. Pengetahuan, sikap dan perilaku ibu dalam pemenuhan gizi balita: Sebuah survai. Jurnal Keperawatan Indonesia 2014; 17:88-94.

17. Freitas FR, Moraes DEB, Warkentin S, et al. Maternal restrictive feeding practices for child weight control and associated characteristics. J Pediat 2019;95:201-8.

18. Dranesia A, Wanda D, Hayati H. Pressure to eat is the most determinant factor of stunting in children under 5 years of age in Kerinci region, Indonesia. Enferm Clin 2019;29:81-6.

19. Harbron J, Booley S, Najaar B, Day CE. Responsive feeding: Establishing healthy eating behaviour early on in life. S Afr J Clin Nutr 2013;26:S141-9.

20. Wondafrash M, Amsalu T, Woldie M. Feeding styles of caregivers of children 6-23 months of age in Derashe special district. BMC Public Health 2012;12:1-8.

21. Wendhiani M. Riwayat penyakit infeksi (ISPA dan diare) sebagai faktor dominan kejadian stunting pada siswa kelas 1 SD di Jakarta Pusat tahun 2016. [unpblished thesis]. Depok: Universitas Indonesia; 2016.

22. Isnaini F. Faktor dominan penyebab stunting usia 12-23 bulan di posyandu terpilih Kelurahan Depok Kota Depok tahun 2014. [unpublished thesis]. Depok: Universitas Indonesia; 2014.

23. Aridiyah FO, Rohmawati N, Ririanty M. Faktor-faktor yang mempengaruhi kejadian stunting pada anak balita di wilayah pedesaan dan perkotaan. e-Jurnal Pustaka Kesehatan 2015;3:163-70. 